\title{
Pelatihan Modul Pembelajaran Menggunakan MS. Word Pada Guru SMKN 1 Jarai
}

\author{
Alfis Arif \\ Program Studi Teknik Informatika; Sekolah Tinggi Teknologi Pagaralam (STTP) \\ Jl. M. Siagim No.75 Kel. Karang Dalo, Dempo Tengah, Kota Pagar Alam \\ Telp/Fax: (0730) 621916 \\ e-mail: alfisarif@yahoo.com.
}

Abstrak

Pengabdian kepada masyarakat (PkM) merupakan kewajiban yang harus dilaksanakan oleh civitas perguruan tinggi termasuk civitas STTP, semangat berbagi dipupuk dan dibina sehingga hubungan sosial secara individu dan secara institusi berjalan dengan baik. Pelatihan pembuatan modul pembelajaran menggunakan Microsoft office word bagi Guru SMKN 1 Jarai dilakukan sebagai implementasi dari semangat berbagi civitas akademika STTP, pelatihan dilakukan dengan metode langsung praktek dan penjelasan yang detail, agar pelatihan berjalan lancar dan tepat sasaran maka dilakukan tes untuk mengetahui tingkat pemahaman peserta pelatihan dilakukan dengan pre dan pos tes. Pada awal pelaksanaan pelatihan dilakukan penjelasan tentang pembuatan modul pembelajaran yang baik, selanjutnya dilakukan setelah konsep dan materi pendahuluan siap dilanjutkan dengan membuat pada Microsoft office word, agar menarik maka dilakukan pengolahan data (editing) pada word. Dari haril pre dan pos tes diketahui bahwa kemampuan peserta kurang bagus karena jarang menggunakan komputer, terutama untuk peserta yang sudah lanjut usia, hasil pre tes menunjukan kemampuan editing word peserta kurang sehingga pelatihan lebih banyak dilakukan praktek dan aplikasi secara langsung, berikutnya pada hasil pos tes diketahui tingkat pemahaman peserta untuk mengedit modul sangat baik, dan berhasil membuat modul pembelajaran.

Kata kunci-Pelatihan, berbagi, word, Pengabdian, Modul.

\section{PENDAHULUAN.}

Perkembangan Teknologi informasi dan komunikasi khususnya teknologi yang mendukung Media pembelajaran saat ini sangat banyak dan menawarkan kemudahan-kemudahan sesuai ke unggulan masing-masing [3], salah satunya adalah Ms. Word yang bisa di manfaatkan sebagai sarana pembuatan modul. Media ini sangat banyak sekali digunakan di sebagai sarana pengolahan data yang sangat familiar.

Penggunaan Ms. Word sebagai media/sarana pembuatan modul ini sangat di sarankan karena memiliki menu-menu yang sesuai dengan standar penulisan yang di sarankan oleh para ahli yang kompeten, sehingga pada saat penyusunan pada Ms. Word ini penulis tinggal klik menu-menu yang di maksud maka akan di dapat hasil tulisan yang baik (standar), selain itu Ms. Word merupakan software pengolah kata/data yang include dalam software dalam sistem komputer dan biasanya benar-benar atau merupakan software asli yang di buat oleh Microsoft sehingga tidak akan ditemui bagian menu yang rusak (crash), selain itu apa bila ingin meng-upgrade, atau mengganti ke versi terbaru Microsoft menyediakan dengan mudah. Dari pemaparan diatas dituntu agar para Guru bidang studi harus selalu meningkatkan kualitas pembelajaran dengan menggunakan semua resource terkait, sehingga dipandang perlu untuk diadakan pelatihan pembuatan modul pembelajaran ini [1].

Materi yang disampaikan harus ditulis dalam sarana yang disebut dengan modul, modul diolah datanya menggunakan Microsoft office word, pengolahan data yang baik dapat meningkatkan minat bahkan pemahaman pembaca terhadap materi yang ada dalam modul belajar, tentu penulisannya harus berdasarkan kaidah dan aturan penulisan baku, maka yang umum dalam hal ini sering di pergunakan Microsoft office word dari berbagai versi yang ada [2], sehingga pada 
pengabdian ini diberi judul: Pelatihan Modul Pembelajaran Menggunakan Ms. Word Pada Guru SMKN 1 Jarai. Karena pelatihan dilaksanakan di SMKN 1 Jarai Lahat.

\section{METODE.}

Pengabdian yang dilaksanakan ini secara langsung, artinya penjelasan dan langsung di praktekan, selain itu dilengkapi modul pelatihan, proyektor, dan peserta pelatihan dapat secara langsung bertanya tentang materi secara langsung pada narasumber [4].

\subsection{Pengabdian Pada Masyarakat (PkM).}

Kegiatan Pengabdian masyarakat merupakan kegiatan bertujuan membantu masyarakat dalam beraktivitas tanpa mengharapkan imbalan dalam bentuk apapun [5]. Secara umum program ini dirancang berbagai universitas atau institut di Indonesia untuk memberikan kontribusi nyata bagi bangsa, khususnya dalam mengembangkan kesejahteraan dan kemajuan bangsa. Kegiatan Pengabdian Masyarakat merupakan salah satu bagian dari Tri Dharma Perguruan Tinggi.

\subsection{Modul Pembelajaran.}

Modul pembelajaran merupakan satuan program belajar mengajar terkecil [6], yang dipelajari siswa sendiri secara perseorangan atau diajarkan siswa pada dirinya sendiri (selfinstructional) (Winkel, 2009:472). Modul pembelajaran merupakan bahan ajar disusun secara sistematis dan menarik mencakup isi materi, metode dan evaluasi yang bisa digunakan mandiri untuk mencapai kompetensi diharapkan (Anwar, 2010). Menurut Goldschmid, Modul pembelajaran sebagai sejenis satuan kegiatan belajar terencana, di desain guna membantu siswa menyelesaikan tujuan-tujuan tertentu [7]. Modul adalah semacam paket program untuk keperluan belajar (Wijaya, 1988:128). Vembriarto (1987:20), menyatakan bahwa suatu modul pembelajaran suatu paket pengajaran yang memuat satu unit konsep daripada bahan pelajaran. Pengajaran modul merupakan usaha penyelanggaraan pengajaran individual yang memungkinkan siswa menguasai satu unit bahan pelajaran sebelum dia beralih kepada unit berikutnya. Berdasarkan beberapa pengertian modul di atas maka dapat disimpulkan bahwa modul pembelajaran adalah salah satu bentuk bahan ajar yang dikemas secara sistematis dan menarik sehingga mudah untuk dipelajari secara mandiri.

\section{Ciri-ciri/ Karakteristik Modul}

Modul pembelajaran merupakan satu bahan belajar yang dimanfaatkan siswa secara mandiri. Modul yang baik harus disusun secara sistematis, menarik, dan jelas [8]. Modul dapat digunakan kapanpun dan dimanapun sesuai kebutuhan siswa. Anwar (2010), menyatakan bahwa karakteristik modul pembelajaran sebagai berikut :

1. Self instructional, Siswa mampu membelajarkan diri sendiri, tidak tergantung pada pihak lain.

2. Self contained, Seluruh materi pembelajaran dari satu unit kompetensi dipelajari terdapat didalam satu modul utuh.

3. Stand alone, Modul yang dikembangkan tidak tergantung pada media lain atau tidak harus digunakan bersama-sama dengan media lain.

4. Adaptif, Modul hendaknya memiliki daya adaptif tinggi terhadap perkembangan IPTEK.

5. User friendly, Modul hendaknya memenuhi kaidah bersahabat/akrab dengan pemakainya.

6. Konsistensi, Konsisten dalam penggunaan font, spasi, dan tata letak.

Menurut Wijaya (1988:129), ciri-ciri pengajaran modul pembelajaran adalah :

1. Siswa dapat belajar individual, ia belajar dengan aktif tanpa bantuan maksimal dari guru.

2. Tujuan pelajaran dirumuskan khusus. Rumusan tujuan bersumber perubahan tingkah laku.

3. Tujuan dirumuskan secara khusus sehingga perubahan tingkah laku yang terjadi pada diri siswa segera diketahui. Perubahan tingkah laku diharapkan sampai $75 \%$ penguasaan tuntas.

4. Membuka kesempatan pada siswa untuk maju berkelanjutan menurut kemampuannya.

5. Modul merupakan paket pengajaran yang bersifat self-instruction, dengan belajar seperti ini, modul membuka kesempatan kepada siswa untuk mengembangkan dirinya secara optimal.

6. Modul memiliki daya informasi yang cukup kuat. Unsur asosiasi, struktur, dan urutan bahan pelajaran terbentuk sedemikian rupa sehingga siswa secara spontan mempelajarinya.

7. Modul banyak memberikan kesempatan kepada siswa untuk berbuat aktif. 


\section{Kelemahan Pembelajaran dengan Menggunakan Modul}

Belajar menggunakan modul disebut dengan belajar mandiri [9]. Menurut Suparman (1993:197), menyatakan bentuk kegiatan belajar mandiri ini mempunyai kekurangan sebagai berikut :

1. Biaya pengembangan bahan tinggi dan waktu yang dibutuhkan lama.

2. Menentukan disiplin belajar yang tinggi yang mungkin kurang dimiliki oleh siswa pada umumnya dan siswa yang belum matang pada khususnya.

3. Membutuhkan ketekunan lebih tinggi dari fasilitator untuk terus mamantau proses belajar siswa, memberi motivasi dan konsultasi secara individu setiap waktu siswa membutuhkan.

Tjipto (1992:72), juga mengungkapkan beberapa hal yang memberatkan belajar dengan menggunakan modul, yaitu :

1. Kegiatan belajar memerlukan organisasi yang baik

2. Selama proses belajar perlu diadakan beberapa ulangan/ujian, perlu dinilai sesegera mungkin.

\section{Kelebihan Pembelajaran dengan Menggunakan Modul.}

Belajar menggunakan modul banyak manfaatnya [10], siswa dapat bertanggung jawab terhadap kegiatan belajarnya sendiri, pembelajaran dengan modul sangat menghargai perbedaan individu, sehingga siswa dapat belajar sesuai dengan tingkat kemampuannya, maka pembelajaran semakin efektif dan efisien. Tjipto (1991:72), keuntungan belajar dengan modul:

1. Motivasi siswa dipertinggi karena setiap kali siswa mengerjakan tugas pelajaran dibatasi dengan jelas dan yang sesuai dengan kemampuannya.

2. Sesudah pelajaran selesai guru dan siswa mengetahui benar siswa yang berhasil dengan baik dan mana yang kurang berhasil.

3. Siswa mencapai hasil yang sesuai dengan kemampuannya.

4. Beban belajar terbagi lebih merata sepanjang semester.

5. Pendidikan lebih berdaya guna.

Selain itu Santyasa (Suryaningsih, 2010:31), juga menyebutkan beberapa keuntungan yang diperoleh dari pembelajaran dengan penerapan modul adalah sebagai berikut :

1. Meningkatkan motivasi siswa, karena setiap kali mengerjakan tugas pelajaran yang dibatasi dengan jelas dan sesuai dengan kemampuan.

2. Setelah dilakukan evaluasi, guru dan siswa mengetahui benar, pada modul yang mana siswa telah berhasil dan pada bagian modul yang mana mereka belum berhasil.

3. Bahan pelajaran terbagi lebih merata dalam satu semester.

4. Pendidikan lebih berdaya guna, karena bahan pelajaran disusun menurut jenjang akademik.

\subsection{Edit Word.}

Banyak orang yang ketika mengerjakan tugas dengan anggota kelompok menghabiskan banyak waktu untuk 'menunggu giliran' mengedit satu dokumen yang sama. Belum lagi harus mengunduh banyak file yang sebetulnya sama (hanya sedikit berbeda di bagian-bagian tertentu) dengan nama yang bertumpuk untuk bisa digabungkan menjadi dokumen yang utuh, seperti 'file tugas 1 bagian Anu.doc', 'file tugas 1 bagian Bello.doc', 'file tugas 1 bagian Titi.doc.' Ini hanya akan membuat folder berantakan dan membingungkan dalam pengerjaan tugas [11]. Untungnya, Microsoft Word menawarkan sebuah alternatif gratis untuk permasalahan ini. Software populer ini memungkinkan penggunanya untuk mengedit satu file yang sama secara bersamaan. Asalkan perangkat terhubung internet, fasilitas ini dapat dengan mudah dimanfaatkan. Dilansir dari laman resminya, Microsoft Word mengklaim fasilitasnya ini dapat membuat pekerjaan kelompok jadi lebih cepat dan bisa diakses di tiga versi Word, yakni Word 2010, Word 2013, dan Word for Mac 2011. Berikut langkah-langkah agar dokumen Word diedit secara bersamaan oleh beberapa orang.

a. Simpan file dokumen kedalam OneDrive atau Share Point Online. Untuk medapatkan perintah ini, klik file $>$ save as.

b. Selanjutnya cari tombol 'Share' untuk membagi file pada alamat email anggota kelompok.

c. Tetapkan izin mengakses anggota dengan meng-klik "Can edit" (selected by default).

d. Masukan pesan jika diperlukan, lalu pada perintah "Automatically share changes" klik "Always." Perintah "Always" akan membuat setiap anggota dapat melihat perubahan dokumen secara real time tepat saat anggota lain mengedit. 
e. Klik Share.

f. Ketika anggota kelompok yang diundang mengklik link yang terkirim melalui email mereka, dokumen akan terbuka dalam versi Word atau Word Online jika mereka tidak menginstal program Word di desktop. Mereka hanya perlu untuk memberikan perintah izin untuk dapat mengakses dokumen dan melihat editing real time. Anggota juga dapat melihat jumlah anggota lain, dan aktivitas mereka seperti masuk atau meninggalkan dokumen.

Gangguan biasanya muncul seperti anggota tidak dapat mengakses link yang dibagikan. Menurut Support Office, untuk permasalahan ini pastikan untuk tidak memberikan perintah pada dokumen yang dapat mencegah penulis lain mengedit dokumen di Word untuk web. Misalnya, jangan gunakan fitur izin seperti pembatasan pengeditan atau menandai dokumen sebagai final. Jika ingin membatasi akses ke dokumen, gunakan fitur izin tempat dokumen disimpan (OneDrive, Office 365, atau SharePoint). Selain itu pastikan sambungan internet dalam kondisi yang baik agar dapat mendukung pengerjaan ini.

\subsection{Word Office.}

Aplikasi pengolah kata seperti Microsoft Word merupakan aplikasi yang paling populer. Walau pun saat anda melamar pekerjaan, memahami Microsoft Word mungkin tidak menjadi kewajiban, namun sangat penting sekali bagi kita untuk memiliki kemampuan dasarnya. Dan di artikel ini, anda akan mempelajari langkah belajar Microsoft Word dengan cepat.

\section{Hal-hal yang bisa dibuat dengan Microsoft Word/}

Bagi yang belum pernah menggunakan Microsoft Word, aplikasi ini dapat melakukan banyak hal. Karena Microsoft Word yaitu aplikasi pengolah kata, berarti anda akan berurusan dengan semua hal yang berbentuk kata, kalimat, dan paragraf. Berikut beberapa hal yang bisa anda buat dengan Microsoft Word sebagai gambaran bagi kita untuk mempelajarinya:

- Membuat dokumen jenis apapun seperti proposal, makalah, dan bahkan dokumen skala besar seperti buku dan novel

- Membuat sertifikat

- Membuat kartu ucapan, kartu nama, dan sejenisnya

- Membuat brosur, pamflet, dan beberapa macam media iklan dasar lainnya

- Membuat absensi, surat, dan sejenisnya

- Dan berbagai macam jenis media kertas lainnya

Apapun pekerjaan anda, kemungkinan besar anda diminta menggunakan atau belajar Microsoft

Word sangatlah besar. Untuk itu, mari kita pelajari bersama dengan membaca artikel ini.

\section{Persiapan}

Berikut 2 hal yang perlu anda siapkan sebelum mulai belajar Microsoft Word.

\section{Menginstall Microsoft Office 2016/2019/365}

Penulis menggunakan Microsoft Office 365 selama menulis artikel ini dengan update yang paling baru. Sebagai rekomendasi, versi Office minimal yang harus anda gunakan adalah Microsoft Office 2010 atau yang paling baru. Jika anda menggunakan Office 2007 atau Office 2003, terlalu banyak fitur yang tertinggal, sehingga sangat disarankan agar anda menggunakan yang lebih baru. Walau artikel dibuat dengan Office 2016/365, tentu anda bisa mengikutinya juga jika anda menggunakan Office 2007 hingga Office 2013. Office 2003 tidak didukung karena perbedannya sudah sangat jauh.

\section{Menggunakan satuan Centimeter}

Dalam membuat dokumen, biasanya kita dihadapi dengan pengukuran. Microsoft Word secara default menggunakan inch. Di Indonesia, biasanya kita menggunakan Centimeter, sehingga perlu kita ubah dahulu dan agar sesuai dengan artikel belajar Microsoft Word kali ini. 


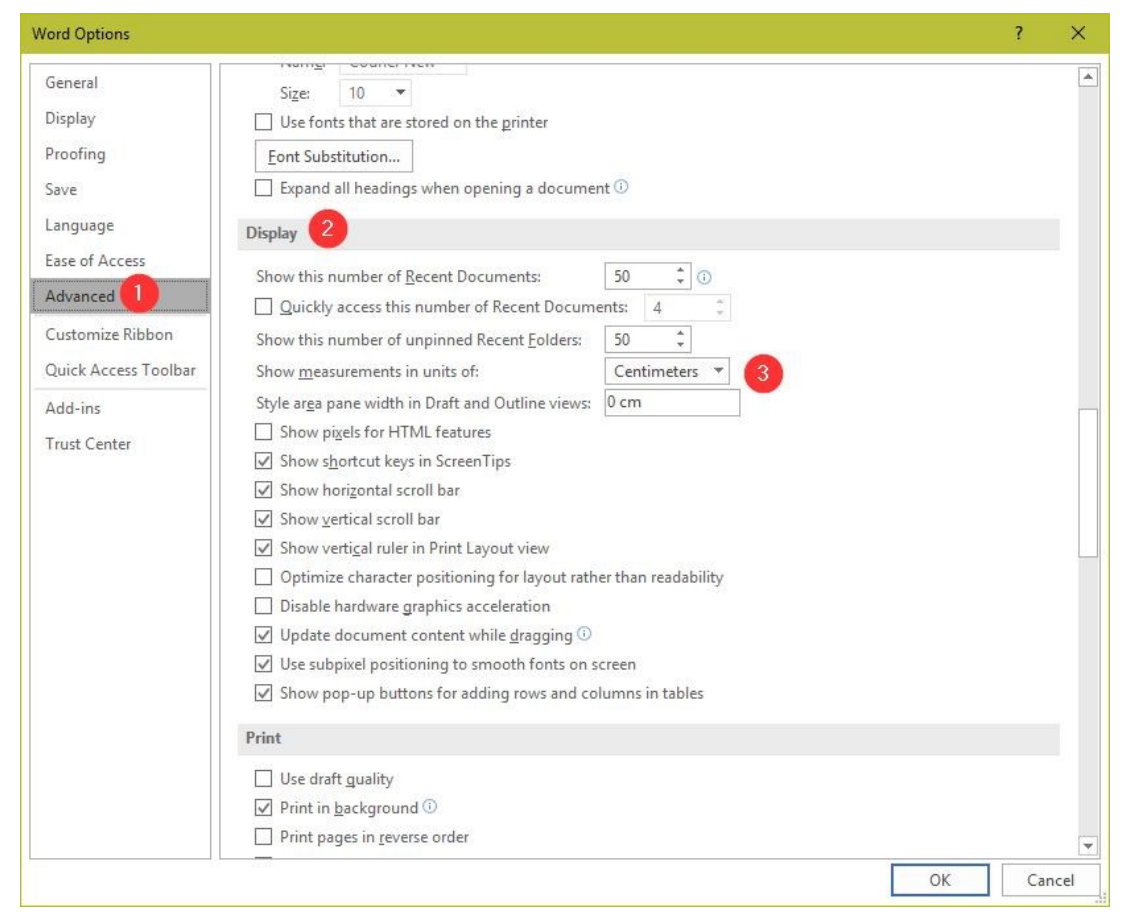

Gambar 1. Centimeter word

Cara mengubahnya adalah klik File $>$ Options $>$ klik tab "Advanced" (1). Kemudian, arahkan ke bagian "Display" (2) dan pilih "Centimeter" pada "Show measurements in units of:" (3). Klik OK jika sudah.

\section{Istilah-istilah yang digunakan di artikel ini}

Artikel ini akan dibuat dengan studi kasus, dimana kita akan sama-sama mencoba dari awal, sehingga bukan hanya penjelasan saja, melainkan juga dengan praktek. Oleh karena itu, perlu kita pelajari bersama beberapa istilah yang akan kita pakai untuk belajar Microsoft Word:

- Dokumen: Istilah yang akan kita gunakan untuk apapun tulisan yang akan ada buat. Jika anda membuat sertifikat, makalah, surat, atau apapun itu, kita akan sama-sama menyebutnya sebagai dokumen.

- Tab: Istilah yang kita gunakan untuk merujuk ke $t a b /$ menu di Microsoft Word. Ada 10 tab/menu seperti File, Home, Insert, Design, Layout, dan lain sebagainya.

\subsection{Pre \& Pos Tes.}

Pre Test.

Yaitu suatu bentuk pertanyaan, yang dilontarkan guru kepada muridnya sebelum memulai suatu pelajaran. Pertanyaan yang ditanya adalah materi yang akan diajar pada hari itu (materi baru). Pertanyaan itu biasanya dilakukan guru di awal pembukaan pelajaran. Pre test diberikan dengan maksud untuk mengetahui apakah ada diantara murid yang sudah mengetahui mengenai materi yang akan diajarkan. Pre test juga bisa di artikan sebagai kegiatan menguji tingkatan pengetahuan siswa terhadap materi yang akan disampaikan, kegiatan pre test dilakukan sebelum kegiatan pengajaran diberikan. Adapun manfaat dari diadakannya pree test adalah untuk mengetahui kemampuan awal siswa mengenai pelajaran yang disampaikan. Dengan mengetahui kemampuan awal siswa ini, guru akan dapat menentukan cara penyampaian pelajaran yang akan di tempuhnya nanti.

Post Test.

Post test merupakan bentuk pertanyaan yang diberikan setelah pelajaran/materi telah disampaikan. Singkatnya, post test adalah evalausi akhir saat materi yang di ajarkan pada hari itu telah diberikan yang mana seorang guru memberikan post test dengan maksud apakah murid sudah mengerti dan memahami mengenai materi yang baru saja diberikan 
pada hari itu. Manfaat dari diadakannya post test ini adalah untuk memperoleh gambaran tentang kemampuan yang dicapai setelah berakhirnya penyampaian pelajaran. Hasil post test ini dibandingkan dengan hasil pree test yang telah dilakukan sehingga akan diketahui seberapa jauh efek atau pengaruh dari pengajaran yang telah dilakukan, disamping sekaligus dapat diketahui bagian bagian mana dari bahan pengajaran yang masih belum dipahami oleh sebagian besar siswa.

\subsection{Penyelesaian Masalah.}

Permasalahan tempat pengabdian adalah keterbatasan kemampuan peserta pelatihan terhadap teknologi, atau memanfaatkan aplikasi word dalam membuat modul maka pengabdian ini adalah melatih peserta dalam mengolah data dan membuat modul menjadi lebih menarik sehingga siswa yang membaca modul yang dibuat merasa nyaman dan mudah memahami modul pembelajaran, manfaat yang lain siswa menjadi mudah karena kapan saja siswa dapat melakukan belajar sehingga lebih banyak kesempatan belajar.

\section{PEMBAHASAN DAN HASIL.}

3.1. Realisasi \& Pemecahan Masalah.

Pelatihan dilakukan selama satu hari dengan peserta Guru dan Pegawai TU SD SMKN 1

Jarai, pada awal pelatihan narasumber untuk mengetahui tingkat pemahaman peserta tentang modul pembelajaran dilakukan pre tes, hasilnya mereka cukup memahami tentang modul pembelajaran tetapi belum memahami terlalu baik penggunaan word untuk aplikasi pada pengolahan data (Modul), maka berikut rincian dari kegiatan pengabdian yang dilaksanakan:

Tabel 1. Kegiatan

\begin{tabular}{|l|l|c|}
\hline \multicolumn{1}{|c|}{ Waktu } & \multicolumn{1}{|c|}{ Materi } & Penyaji \\
\hline $08.00-09.00$ & $\begin{array}{l}\text { Pre Test } \\
\text { Pengenalan teori tentang pembuatan modul } \\
\text { berdasarkan kalayakan pembuatan modul dan teori } \\
\text { tentang office word. }\end{array}$ & \\
\cline { 1 - 2 } $09.30-12.00$ & $\begin{array}{l}\text { Belajar mengolah data dengan word office dan } \\
\text { melakukan edit data. }\end{array}$ & \\
$12.00-12.30$ & $\begin{array}{l}\text { Ishoma } \\
12.30-13.00\end{array}$ & Alfis Arif \\
& Post-test & \\
\hline
\end{tabular}

Berdasarkan rincian kegiatan seperti tabel 1. Rincian kegiatan, maka dari sejumlah peserta yang ada sebanyak $10 \%$ sudah memahami cukup baik tata cara menyampaikan atau membuat materi dengan modul, dan sudah pernah membuat modul. 20\% mengetahui teknik membuat modul tetapi belum pernah membuat modul pembelajaran dan 70 persen memahami modul tetapi tidak pernah membuat modul dan dari seluruh peserta yang sudah biasa menulis dengan word office hanya $5 \%$ saja, sehingga berdasarkan hal tersebut pengabdi menggap bahwa seluruh peserta memahami dan mengerti tentang modul tetapi belum begitu baik dalam mengolah data dengan word sehingga pelatihan pembuatan modul diarahkan pada tata cara mengolah data menggunakan word, bagaimana menyusun sebuah data sengingga menjadi modul.

Pada tahap kedua setelah pre tes dilakukan pengenalan teori word office dan tips serta trik mengolah serta mengedit data menggunakan word, berikutnya setelah peserta paham dengan materi dan mengetahui tools dan fungsi fitur yang ada pada word dilanjutkan dengan melakukan pembuatan modul pembelajaran, dimana peserta pelatihan diharuskan langsung mengolah data yang merupakan bahan ajar yang diberikan dikelas, artinya peserta dengan bimbingan narasumber dipersilahkan langsung membuat modul pembelajaran, dimana pada saat terdapat permasalahan yang ditemui seluruh peserta dapat langsung bertanya permasalahan yang ditemui kepada narasumber, terakhir setelah selesai pelatihan dilaksanakan dilakukan pos tes untuk mengetahui tingkat pemahaman peserta terhadap materi dan kemampuan peserta terhadap pembuatan modul menggunakan word. 


\subsection{Pembahasan \& Hasil.}

Sesuai urutan dan rincian kegiatan diatas (Tabel 1), maka yang terakhir dari kegiatan dilakukan tes untuk mengetahui keberhasilan dari kegiatan yang dilakukan pada pelatihan pembuatan modul menggunakan Microsoft office word, pada SMKN 1 Jarai maka uraian keberhasilan dari peltihan ini diuraikan oleh tabel dibawah ini:

Tabel 2. Keberhasilan Pelaksanaan Kegiatan

\begin{tabular}{|l|l|}
\hline \multicolumn{1}{|c|}{ Materi } & \multicolumn{1}{|c|}{ Hasil } \\
\hline $\begin{array}{l}\text { Pendahuluan tips dan trik } \\
\text { membuat modul ajar }\end{array}$ & $\begin{array}{l}\text { Seluruh peserta memahami dengan baik tata cara pembuatan } \\
\text { modul pembelajaran yang menarik sehingga, siswa tidak } \\
\text { bosan membacanya ditambahi dengan gambar dan kartun } \\
\text { contohnya. }\end{array}$ \\
\hline Pengenalan office word & $\begin{array}{l}\text { Peserta paham tools yang ada pada word dan memahami cara } \\
\text { penggunaannya. }\end{array}$ \\
\hline Pengolahan data dengan word & $\begin{array}{l}\text { Seluruh peserta mampu melakukan pengetikan data pada } \\
\text { word \& mengaplikasikan seluruh fungsi dan manfaat fitur } \\
\text { berdasarkan bimbingan narasumber. }\end{array}$ \\
\hline Editing data & $\begin{array}{l}\text { Peserta melakukan edit dan pengolahan data sehingga modul } \\
\text { menjadi lebih menarik dengan batuan dari narasumber. }\end{array}$ \\
\hline
\end{tabular}

Berdasarkan identifikasi dan penilaian sesuai aturan pos tes maka terhadap seluruh peserta yang mengikuti pelatihan bahwa $100 \%$ peserta memahami dan bisa membuat modul menggunakan word sehingga pelatihan yang dilakukan berhasil, maka berikut hasil identifikasi keberhasilan secara umum yang dilakukan terhadap peserta:

a. Para peserta, guru dan karyawan SMKN 1 Jarai mampu mengolah data menggunakan word dan bisa diaplikasikan bukan hanya buat modul saja, tetapi mereka bahkan bisa melakukan pembuatan surat menyurat dinas menggunakan aplikasi word.

b. Peserta pelatihan menjadi memiliki pemaham lebih tentang teknologi, terutama teknologi informasi yang umum dikuasai untuk mendukung pekerjaan seperti word ini.

c. Pimpinan SMKN 1 Jarai merasa terbantu dengan ada pengabdian, sehingga pegawainya menjadi lebih memahami teknologi.

\section{KESIMPULAN}

Pengabdian kepada masyarakat (PkM) yang dilakukan pada para Guru dan Karyawan SMKN 1 Jarai, maka diperoleh kesimpulan sebagai berikut:

a. Menambah pengetahuan dan pengalaman lebih kepada peserta pelatihan dalam hal ini para Guru dan Karyawan SMKN 1 Jarai dalam bidang teknologi informasi.

b. Meningkatkan rasa percaya diri para peserta pelatihan karyawan dan Guru dalam memahami cara membuat modul, dan tulisan surat menyurat.

c. Dengan pemahaman yang baik dari guru terhadap metode penyampaian materi yang baik dapat lebih memperbaiki kualitas hasil pembelajaran.

d. Dapat meningkatkan kemampuan siswa karena sarana belajar yang baik, dan banyak sehingga mereka bisa belajar dimana saja.

\section{SARAN}

Berdasarkan pelatihan yang dilaksanakan pada kegiatan PkM ini, maka pengabdi dapat memberikan beberapa sarana:

a. Penambahan waktu pelatihan

b. Materi ditambah/ lebih kompleks dan lebih banyak contoh. 


\section{UCAPAN TERIMA KASIH}

Penulis mengucapkan terima kasih kepada Panitia KKN dan Pengabdian bagi Dosen, terima kasih kepada keluarga, kawan-kawan dosen.

\section{DAFTAR PUSTAKA}

[1] Hutchinson E. Sarah and Sawyer C. Stacey, 2000, Computers, Communications \& Information, McGraw Hill Companies Inc.

[2] Indonesia Services Education HP Tim, 2001, Manajemen Sistem Belajar Di Dunia Maya, Majalah Info Komputer.

[3] Muslim, B. 2018. Pelatihan aplikasi editing video dengan filmora., Laporan Pengabdian Kepada Masyarakat, LPPM STT Pagaralam.Muslim, B. 2018. Pelatihan Pembuatan Blog

[4] Bagi Guru Ma Ponpes Darul Mutaqin Kota Pagaralam. NGABDIMAS. Vol 1. No.1. Bulan Juni, Hal. 6-11Sadiman, A.S., Rahardjo, R., Haryono, A., \& Rahardjito. 2006. Media

[5] : Pengertian, pengembangan, dan pemanfaatan. Jakarta: Rajagrafindo

[6] Persada.Menristekdikti. 2016. Panduan Pelaksanaan Penelitian dan Pengabdian Masyarakat di Perguruan Tinggi Edisi X Tahun 2016. hlm. 4B. Muslim, Pengantar

[7] teknologi informasi. Yogyakarta: Deepublish, 2017.Muslim, B. (2018). Analisis system

[8] informasi (SI) terintegrasi di Perguruan Tinggi (PT) (Studi Kasus: STT Pagaralam). Jurnal Teknologi Informasi MURA, Vol 10. Page 83-91.

[9] Muslim, B (2014). Analisis rencana aplikasi teknologi informasi pada STT Pagar Alam. Proseding semnastik dan Magma. Issue: Aplikasi Teknologi dan sistem Informasi. PPP UBD Pres. Pages 397-404.

[10] M.H Jogiyanto, 1995, Pengenalan Komputer, Andi Offset Yogyakarta.

[11] Horsley, M., Knight, B., \& Huntly, H. 2010. The role of textbooks and other teaching and learning resources in higher education in Australia: Change and continuity in supporting learning. IARTEM 1-Journal. 3(2). 43-61.

[12] Isro'Mukti, Y. (2017). Sistem Informasi Madrasah Aliyah Negeri Pagar Alam Berbasis Web. Indonesian Journal of Computer Science, 6(2), 192-205.

[13] Mukti, Y. (2017). Perencanaan Strategis Sistem Informasi Dan Teknologi Informasi Pada Sekolah Menengah Kejuruan Negeri 2 Pagar Alam. JURNAL ILMIAH BETRIK: Besemah Teknologi Informasi dan Komputer, 8(02), 83-92.

[14] Arif, A., \& Mukti, Y. (2017). Rancang Bangun Website Sekolah Menengah Pertama (SMP) Negeri 8 Kota Pagar Alam. JURNAL ILMIAH BETRIK: Besemah Teknologi Informasi dan Komputer, 8(03), 156-165.

[15] Isro'Mukti, Y. (2018, October). Sistem Informasi Manajemen Aset Sekolah Tinggi Teknologi Pagaralam Berbasis Web. In Seminar Nasional Teknologi Informasi dan Komunikasi (SEMNASTIK) (Vol. 1, No. 1, pp. 632-638).

[16] Mukti, Y. (2018). Rancang Bangun Website Sekolah Dengan Metode User Centered Design (UCD). JURNAL ILMIAH BETRIK: Besemah Teknologi Informasi dan Komputer, 9(02), 84-95.

[17] Mukti, Y. (2018). Pelatihan Maintance Komputer SMAN Pagar Gunung. NGABDIMAS, $1(1), 47-51$. 